\title{
Doxorubicin-Induced Fetal Mesangial Cell Death Occurs Independently of TRPC6 Channel Upregulation but Involves Mitochondrial Generation of Reactive Oxygen Species
}

\author{
Anberitha T. Matthews ${ }^{1}{ }^{\circledR}$, Hitesh Soni ${ }^{1}$, Katherine E. Robinson-Freeman ${ }^{1}$, Theresa A. John ${ }^{1}$, \\ Randal K. Buddington ${ }^{2}$ a and Adebowale Adebiyi ${ }^{1, *}$ (D) \\ 1 Department of Physiology, College of Medicine, University of Tennessee Health Science Center, \\ Memphis, TN 38163, USA; anberitha@gmail.com (A.T.M.); drhiteshsoni@gmail.com (H.S.); \\ krobin39@uthsc.edu (K.E.R.-F.); theresaadebola@yahoo.com (T.A.J.) \\ 2 School of Health Studies, University of Memphis, Memphis, TN 38152, USA; rkb.btf@gmail.com \\ * Correspondence: aadebiyi@uthsc.edu; Tel.: +1-901-448-1868; Fax: +1-901-448-7126
}

\section{check for}

updates

Citation: Matthews, A.T.; Soni, H.; Robinson-Freeman, K.E.; John, T.A.; Buddington, R.K.; Adebiyi, A. Doxorubicin-Induced Fetal Mesangial Cell Death Occurs Independently of TRPC6 Channel Upregulation but Involves Mitochondrial Generation of Reactive Oxygen Species. Int. J. Mol. Sci. 2021, 22, 7589. https://doi.org/ $10.3390 /$ ijms 22147589

Academic Editor: Anindita Das

Received: 18 June 2021

Accepted: 13 July 2021

Published: 15 July 2021

Publisher's Note: MDPI stays neutra with regard to jurisdictional claims in published maps and institutional affiliations.

Copyright: (c) 2021 by the authors. Licensee MDPI, Basel, Switzerland. This article is an open access article distributed under the terms and conditions of the Creative Commons Attribution (CC BY) license (https:// creativecommons.org/licenses/by/ $4.0 /)$.

\begin{abstract}
Doxorubicin (DOX), a category D pregnancy drug, is a chemotherapeutic agent that has been shown in animal studies to induce fetal toxicity, including renal abnormalities. Upregulation of the transient receptor potential cation (TRPC) 6 channel is involved in DOX-induced podocyte apoptosis. We have previously reported that TRPC6-mediated $\mathrm{Ca}^{2+}$ signaling promotes neonatal glomerular mesangial cell (GMC) death. However, it is unknown whether DOX alters mesangial TRPC expression or viability in the fetus. In this study, cell growth was tracked in control and DOX-treated primary GMCs derived from fetal pigs. Live-cell imaging demonstrated that exposure to DOX inhibited the proliferation of fetal pig GMCs and induced cell death. DOX did not alter the TRPC3 expression levels. By contrast, TRPC6 protein expression in the cells was markedly reduced by DOX. DOX treatment also attenuated the TRPC6-mediated intracellular $\mathrm{Ca}^{2+}$ elevation. DOX stimulated mitochondrial reactive oxygen species (mtROS) generation and mitophagy by the GMCs. The DOX-induced mtROS generation and apoptosis were reversed by the mitochondriatargeted antioxidant mitoquinone. These data suggest that DOX-induced fetal pig GMC apoptosis is independent of TRPC6 channel upregulation but requires mtROS production. The mtROS-dependent GMC death may contribute to DOX-induced fetal nephrotoxicity when administered prenatally.
\end{abstract}

Keywords: doxorubicin; TRPC; $\mathrm{Ca}^{2+}$; glomerular mesangial cell; apoptosis; mitochondrial reactive oxygen species

\section{Introduction}

Kidney cells, including mesangial cells, parietal epithelial cells, endothelial cells, and podocytes, sustain the structure and function of the glomerulus. Dysregulation of the associated cell functions is of pathological significance in a wide variety of diseases [1]. The central stalk of the glomerulus contains mesangial cells that line the inter-capillary space (mesangium) and generate extracellular matrix proteins [2,3]. The glomerular mesangial cells (GMCs) produce vasoactive agents and express G-protein-coupled receptors (GPCRs) and ion channels, including the transient receptor potential cation (TRPC) channels [2-5]. Activation of GPCRs and ion channels can contract or relax cultured GMCs to regulate their planar surface area, the physiological significance of which is unresolved in intact kidneys $[2,3]$.

GMCs play critical roles in glomerulogenesis. Similar to endothelial cells, GMCs are recruited into the vascular clefts of developing glomeruli, where they organize the glomerular capillary network [6,7]. Formation of the capillary tuft and the commencement of filtration requires mesangial factors [6,7]. Thus, mesangiolysis and targeted deletion of critical mesangial cell genes, including ephrinB2, Notch, GATA3, and EBF1, have been demonstrated to alter mesangial and capillary loop maturation and impair glomerulogenesis [6-11]. 
Postnatal exposure to nephrotoxic medications, including aminoglycoside antibiotics and nonsteroidal anti-inflammatory drugs, can have short- and long-term adverse effects on immature kidneys and are a significant cause of acute kidney injury (AKI) and chronic kidney disease (CKD) $[12,13]$. Furthermore, since nephrogenesis ends by the 36th week of gestation in humans, medications administered to pregnant women or premature babies before completing nephrogenesis may alter kidney development and cause morphological and functional derangements of the nephrons $[14,15]$. Drug-induced impairment of kidney development may have long-term adverse consequences to kidney and cardiovascular functions.

The anthracycline antibiotic, doxorubicin (DOX), is a potent chemotherapeutic drug used to treat various cancers, including Hodgkin and non-Hodgkin lymphoma, and bone, breast, and liver, and ovarian cancers [16,17]. DOX promotes cardiac fibrosis and ventricular failure [16-19]. DOX treatment can also induce kidney injury and is an established rodent model of CKD [20]. DOX nephrotoxicity is characterized by damage to the glomerular capillaries, proteinuria, tubulointerstitial inflammation, and podocyte effacement [20]. DOX is a pregnancy category D drug as animal studies have shown evidence of toxic cardiac and kidney effects from its in utero exposure [21,22]. Administration of DOX to female rats four weeks before fertilization resulted in the fetuses exhibiting mesangial matrix accumulation, glomerulosclerosis, thickening of the glomerular basement membranes, and tubular injury $[23,24]$. Fetuses of rats that received DOX early in gestation have also been reported to exhibit hydronephrosis, cortical and medullary atrophy, and kidney lesions $[21,25,26]$.

Normal proliferation, differentiation, and survival of kidney cells are critical processes during nephrogenesis $[27,28]$. Since an increase in cell growth or death can result in glomerular injury $[29,30]$, mechanisms that control propagation and senescence are vital. This includes signal transduction pathways that can be modulated by changes in intracellular $\mathrm{Ca}^{2+}$ concentrations $\left(\left[\mathrm{Ca}^{2+}\right]_{\mathrm{i}}\right)$ as $\left[\mathrm{Ca}^{2+}\right]_{\mathrm{i}}$ is a regulator of signal transduction processes controlling the cell cycle and survival [31,32]. Upregulation of TRPC6 channel expression has been demonstrated to contribute to DOX-induced podocyte apoptosis and glomerulosclerosis $[33,34]$. We have reported that TRPC6-mediated $\mathrm{Ca}^{2+}$ signaling promotes neonatal GMC death [35]. Whether DOX alters TRPC6 expression or mesangial viability in fetal GMCs is unclear. In this study, we examined the effects of DOX on fetal pig primary GMCs. We tested the hypothesis that DOX-induced upregulation of TRPC6 expression and TRPC6-dependent $\left[\mathrm{Ca}^{2+}\right]_{\mathrm{i}}$ elevation is associated with fetal GMC apoptosis.

\section{Results}

\subsection{DOX Inhibited Fetal GMC Proliferation}

Figure 1 shows the concentration- and time-response effects of DOX on fetal GMC proliferation. Automatic quantification of proliferation over $72 \mathrm{~h}$ indicated that 1 and $3 \mathrm{nM}$ of DOX did not alter cell growth. Although 10-100 nM of DOX inhibited proliferation, 0.3-10 $\mu \mathrm{M}$ caused the death of the cells less than $30 \mathrm{~h}$ after treatment. These data suggest that DOX impedes proliferation and induces the death of fetal pig GMCs. 
[A]

\section{$\operatorname{Dox}(\mu \mathrm{M})$}

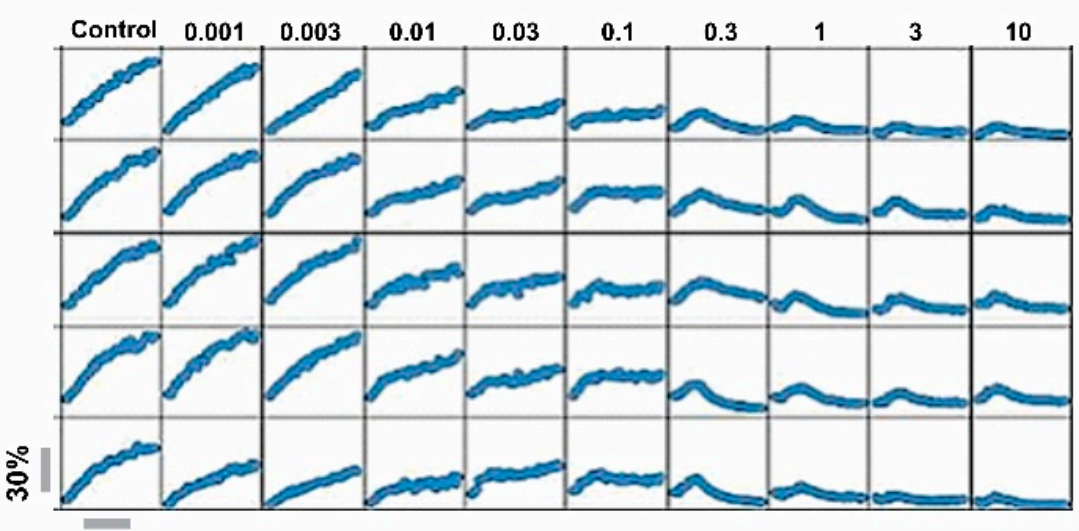

$36 \mathrm{~h}$
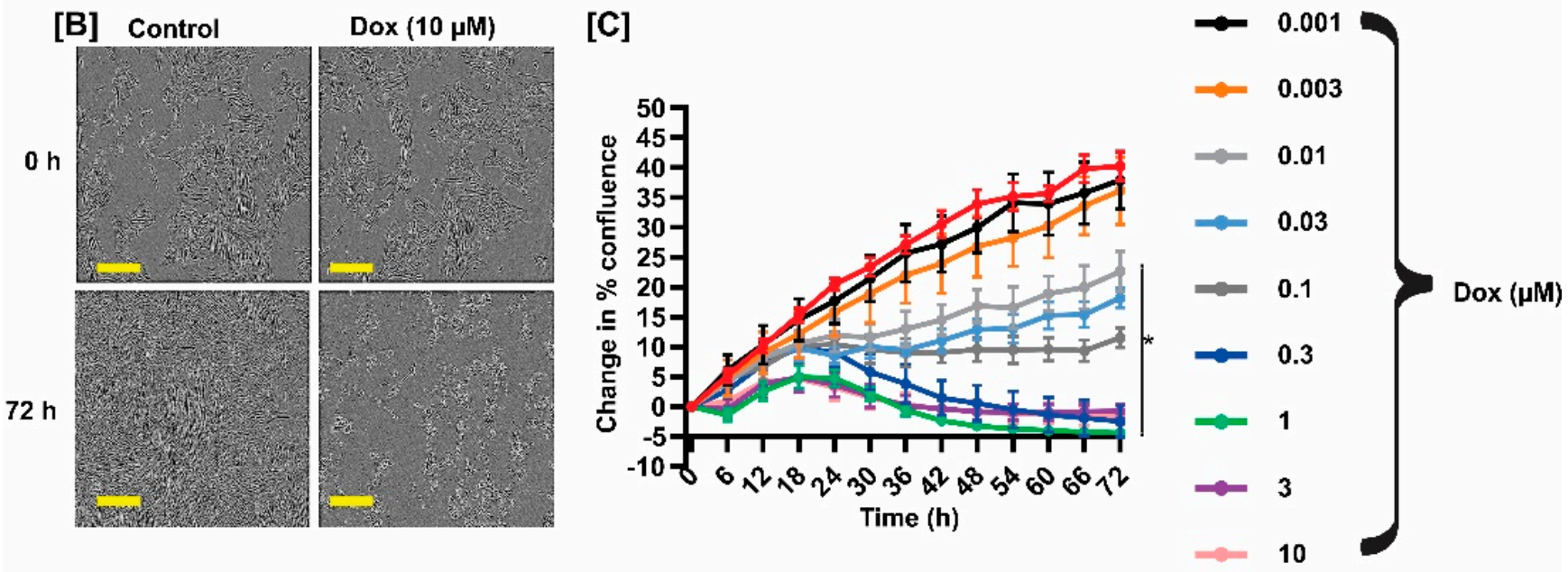

Figure 1. DOX inhibits fetal GMC proliferation. (A) Representative microplate graphs; (B) phase-contrast images; and (C) cell growth curves showing time- and concentration-dependent effect of DOX on fetal pig GMCs. Both control and DOX-treated cells show normal morphology at $0 \mathrm{~h}$. DOX concentrations of 1 and $3 \mathrm{nM}$ did not alter cell growth. Whereas 10-100 $\mathrm{nM}$ of DOX inhibited proliferation and 0.3-10 $\mu \mathrm{M}$ caused the death of the cells less than $30 \mathrm{~h}$ characterized by circular rather than elongated appearance. * $p<0.05$ vs. control (10 nM: 30-72 h; $30 \mathrm{nM}$ : 24-72 h; $100 \mathrm{nM}$ : 30-72 h; 300 nM: 30-72 h; $1 \mu \mathrm{M}$ : 24-72 h; $3 \mu \mathrm{M}$ : 24-72 h; $10 \mu \mathrm{M}$ : 24-72 h) (two-way ANOVA, with Tukey's post hoc test) $(n=5$ each). Scale bar $=300 \mu \mathrm{M}$.

\subsection{DOX Reduced TRPC6 Channel Expression in Fetal GMCs}

Western immunoblotting of protein lysates isolated from fetal pig GMCs revealed TRPC 3 and TRPC6 expression in the cells (Figure 2A-D). Although TRPC 3 expression was not altered, the protein expression levels of TRPC6 were significantly reduced in GMC treated for $18 \mathrm{~h}$ with $100 \mathrm{nM}$ of DOX (Figure 2A-D). 

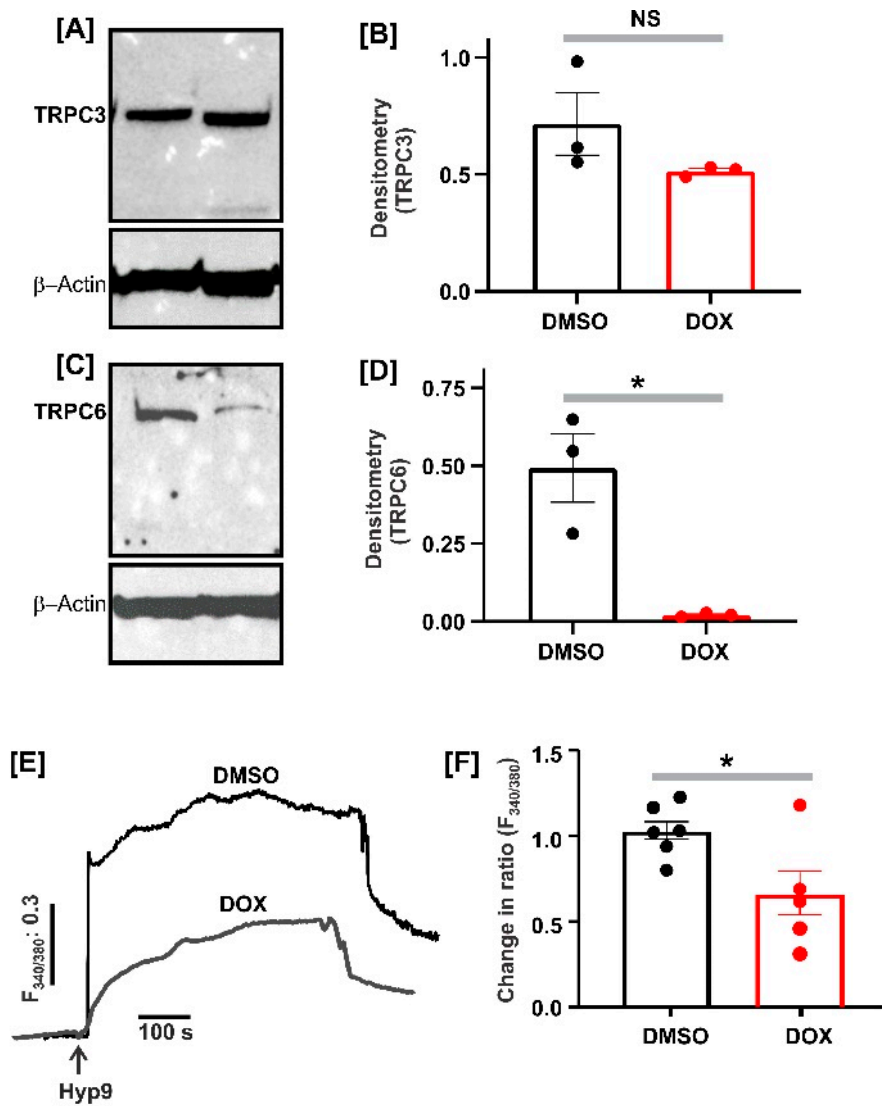

Figure 2. DOX reduces TRPC6 channel expression and TRPC6-mediated $\left[\mathrm{Ca}^{2+}\right]_{i}$ in fetal GMCs. Western blot images and bar charts showing the expression levels of TRPC3 (A,B) and TRPC6 (C,D) in control (DMSO)- and DOX (100 nM)-treated fetal pig GMCs (18 h). (E,F) Exemplar traces and bar charts demonstrating the levels of Hyp9 $(10 \mu \mathrm{M})$ (TRPC6 agonist)-induced $\left[\mathrm{Ca}^{2+}\right]_{\mathrm{i}}$ elevation in control (DMSO)- and DOX (100 nM)-treated fetal GMCs (18 h). ${ }^{*} p<0.05$ vs. control (two-tailed unpaired $t$-test); NS = not significant.

\subsection{DOX Inhibited TRPC6-Mediated $\left[\mathrm{Ca}^{2+}\right]_{i}$ Elevation in Fetal GMCs}

TRPC6 channels regulate neonatal pig GMC $\left[\mathrm{Ca}^{2+}\right]_{\mathrm{i}}$ concentrations [35]. To determine whether DOX modulates TRPC6-dependent $\left[\mathrm{Ca}^{2+}\right]_{\mathrm{i}}$ elevation, we explored the effect of Hyp9, a TRPC6 channel activator on $\left[\mathrm{Ca}^{2+}\right]_{\mathrm{i}}$ levels. Hyp9 increased $\left[\mathrm{Ca}^{2+}\right]_{\mathrm{i}}$ in control fetal pig GMCs (treated with DMSO) (Figure 2E,F). However, DOX treatment attenuated the Hyp9-induced $\left[\mathrm{Ca}^{2+}\right]_{\mathrm{i}}$ elevation by $\sim 36 \%$.

\subsection{DOX Stimulated Mitochondrial ROS Generation in Fetal GMCs}

DOX localizes to the mitochondria $(\mathrm{mt})$ and promotes mt-dependent intracellular ROS generation in various cells. Here, we used the MitoSOX Red fluorogenic dye to evaluate superoxide generation, specifically in the mitochondria of live fetal pig GMCs. Oxidation from MitoSOX Red by superoxide produces red fluorescence, which was amplified in DOXtreated cells (Figure 3A,B). Pretreatment of the cells with the mitochondria-targeted antioxidant mitoquinone (MitoQ) decreased DOX-induced MitoSOX oxidation (Figure 3A,B). Increased mtROS stimulates mitophagy [36-38]; Figure 3C shows that mitophagy was essentially absent in the DMSO-treated fetal pig GMCs but was induced in the DOX-treated cells. Together, these data indicate that DOX stimulates mtROS generation in fetal GMCs. 

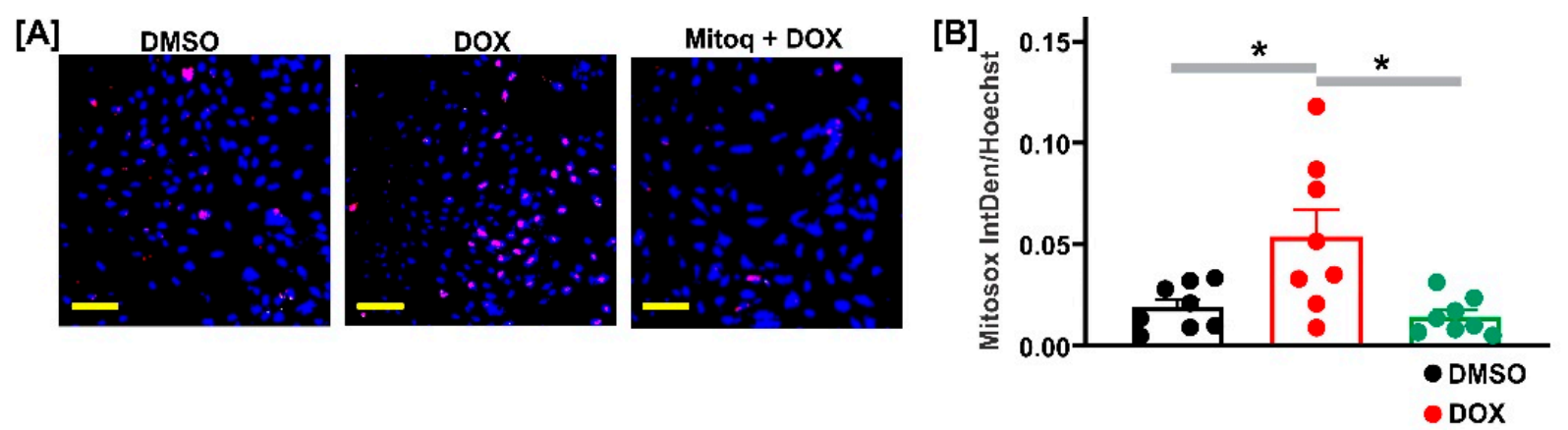

MITOQ+DOX
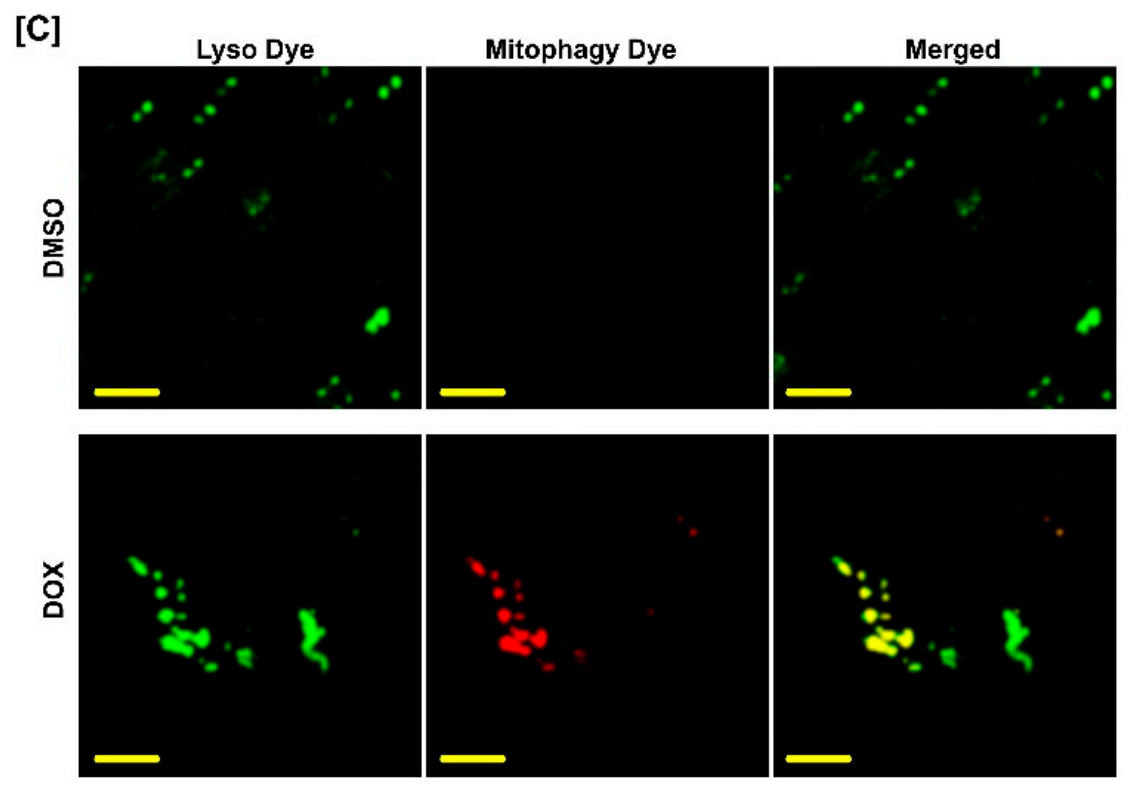

Figure 3. DOX stimulates mtROS generation in fetal GMCs. (A,B) Confocal microscopy images and charts showing increased MitoSOX Red staining (indicating ROS generation) in DOX (100 nM; $30 \mathrm{~min}$ )-treated cells and reversal by the mitochondriatargeted antioxidant mitoquinone (MitoQ $1 \mu \mathrm{M}$ ). (C) Representative confocal microscopy images $(n=4)$ showing induction of the mitophagy dye staining in DOX-treated cells. The mitophagy dye exhibits a weak basal fluorescence, but the fluorescence is induced when injured mitochondria fuse to the lysosome. The Lyso dye detects lysosomes in the cells. ${ }^{*} p<0.05$ vs. DMSO/DOX (one-way ANOVA, with Tukey post hoc test). Scale bar $=100 \mu \mathrm{M}$.

\subsection{MitoQ Reversed DOX-Induced Apoptosis in Fetal GMCs}

Figure 1 indicates significant cell death in the DOX-treated cells. To examine whether DOX induces fetal pig GMC apoptosis, we measured caspase-3/7 activity in the cells. As shown in Figure $4 \mathrm{~A}, \mathrm{~B}, \mathrm{DOX}$ engendered an increase in caspase- $3 / 7$ activity in a concentration- and time-dependent manner. Pretreatment of the cells with MitoQ and Ac-DEVD-CHO (a caspase-3 and caspase-7 inhibitor) reversed DOX-induced caspase-3/7 activation, indicating that mtROS mediates DOX-induced apoptosis in fetal pig GMCs (Figure 4A,B). 

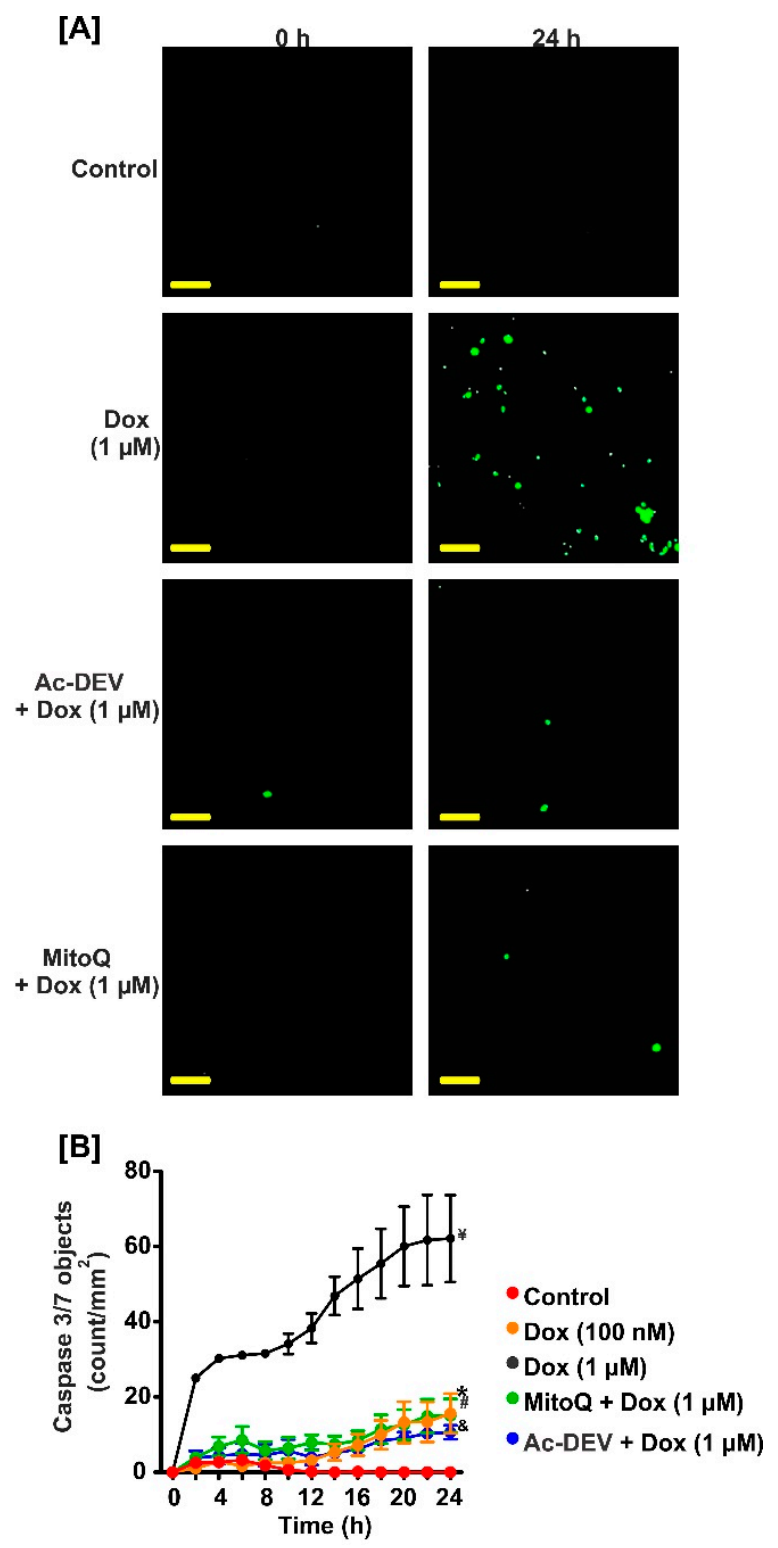

Figure 4. DOX-induced mtROS promotes caspase-3/7 activation in fetal GMCs. (A) Images (green fluorescence staining of the nuclear DNA in apoptotic cells) and (B) caspase 3/7 object count demonstrating that DOX induces apoptosis in fetal GMCs and reversal by MitoQ $(1 \mu \mathrm{M})$ and Ac-DEVD-CHO (50 $\mathrm{\mu M}$; a caspase- 3 and caspase-7 inhibitor). ${ }^{¥} p<0.05$ vs. control $(2-24 \mathrm{~h}) ;{ }^{*} p<0.05$ vs. control $(24 \mathrm{~h})$ \&,\# $p<0.05$ vs. DOX ( $1 \mu \mathrm{M} ; 2-24 \mathrm{~h}$ ) (two-way ANOVA, with Tukey's post hoc test); $n=5$ each. Scale bar $=100 \mu \mathrm{M}$.

\section{Discussion}

The data presented here show that DOX inhibits the proliferation of fetal GMCs. The small and rounded appearance of the cells treated with $\geq 0.3 \mu \mathrm{M}$ of DOX is indicative of cell death. DOX-induced apoptosis was confirmed by a concentration- and time-dependent increase in caspase-3/7 activity in the cells. The apoptotic activity of DOX is consistent with its effects on rat mesangial cells and other kidney cell types, including tubular and glomerular endothelial cells, and podocytes [39-42].

DOX kills cancer cells by inducing double-strand DNA breaks via intercalation into DNA and inhibiting topoisomerase-II-mediated DNA repair [16,43]. DOX also promotes cellular injury by generating deleterious ROS leading to oxidative DNA damage and cell death $[16,43]$. Increased renal TRPC6 expression is associated with podocyte injury 
and death in DOX nephropathy $[33,44,45]$. Treatment of mouse podocytes with DOX caused time-dependent apoptosis and was correlated with an increase in mRNA and protein expression of the TRPC6 channels [34]. Moreover, siRNA-mediated knockdown of TRPC6 reduced DOX-induced apoptosis in cultured mouse podocytes [34]. Together, these studies suggest that TRPC6-dependent $\mathrm{Ca}^{2+}$ signaling contributes to DOX-induced podocyte dysfunction.

TRPC6 is a member of the TRPC3/6/7 subgroup of cation channels within the TRPC family. These $\mathrm{Ca}^{2+}$ permeable channels share approximately $75 \%$ amino acid identity, are gated by diacylglycerol analogs, and co-assemble, forming a functional channel [46,47]. We have previously shown that TRPC 6 activation and successive $\left[\mathrm{Ca}^{2+}\right]_{\mathrm{i}}$ elevation caused apoptosis in primary neonatal pig GMCs [35]. TRPC6-mediated GMC apoptosis was independent of ROS generation but involved induction of the calcineurin/NFAT, FasL/Fas, and caspase signaling pathways [35]. As a first step in determining whether DOX-induced upregulation of TRPC 3 or TRPC6 is involved in fetal GMC apoptosis, we investigated the protein expression levels of these channels in DOX-treated cells. DOX did not change TRPC3 but reduced the protein expression levels of TRPC6 in fetal GMCs. Correspondingly, the TRPC6-mediated increase in $\left[\mathrm{Ca}^{2+}\right]_{i}$ was significantly reduced in cells treated with DOX. These findings indicate that, unlike the podocytes, DOX does not promote TRPC6 upregulation in fetal pig GMCs. Instead, it reduced the expression of the channels. Hence, the TRPC6 channels upregulation may not contribute to fetal pig GMC death. The pathophysiological significance of DOX-induced reduction in TRPC6 protein expression levels requires further investigation.

Anticancer drugs, including DOX, are associated with cell death triggered by mitochondrialdependent and -independent ROS production [48-50]. Oxidative stress-induced alterations in mitochondrial bioenergetics, loss of mitochondrial membrane potential, and disruption to the electron transport chain are mechanisms that underlie DOX-induced cellular dysfunction, especially in the cardiomyocytes [16,43,51,52]. However, the role of ROS in DOX-induced fetal mesangial cell death was unclear. We showed here that DOX engenders mtROS generation in fetal pig GMCs, an effect attenuated by the mitochondria-targeted antioxidant MitoQ. Mitophagy, a selective form of the autophagy mechanism that eliminates injured mitochondria, has been implicated in DOX cardiomyopathy [53-56]. Increased production of mtROS stimulates mitophagy [36-38]. In cardiac cells, DOX produced excessive elimination of the mitochondria via mitophagy [53-56]. Hence, our data showing that DOX triggered mitophagy in fetal pig GMCs supports the concept that DOX induces mtROS generation in the cells and promotes mitochondrial degradation. Furthermore, the reversal of DOX-induced apoptosis by MitoQ indicates that mitochondrial-derived oxidative stress is involved in DOX-induced fetal GMC apoptosis. Hence, pharmacological inhibition of mtROS could be a potential therapy for the treatment of DOX-induced fetal nephrotoxicity.

In summary, we demonstrated that DOX-induced fetal mesangial cell death occurs independently of TRPC 6 channel upregulation but involves mtROS production. Further studies that use whole animal models are necessary to elucidate whether DOX-induced GMC death may contribute to its fetal nephrotoxic effects when administered prenatally.

\section{Materials and Methods}

\subsection{Animals}

Kidneys were harvested from fetuses delivered by caesarian section at 100-105 days of gestation (87-91\% of term) from timed pregnancy sows of the same genetic lineage.

\subsection{Primary GMC Culture}

The fetal pigs were euthanized after delivery by euthasol $(1 \mathrm{~mL} / \mathrm{kg}$; IV) followed by exsanguination (severing the abdominal aorta). After euthanasia, the kidneys were removed and placed in Dulbecco's modified Eagle's medium (DMEM; Life Technologies, Grand Island, NY, USA). Renal glomeruli were isolated from the fetal pigs by serial sieving of renal cortical homogenates using sterile stainless steel meshes. The glomeruli were 
decapsulated and cultured under conditions that favored GMC growth, as previously described [35,57].

\subsection{Live-Cell Imaging}

Real-time cell proliferation and kinetic quantification of apoptosis in fetal pig GMCs were performed using the IncuCyte ZOOM live content microscopy system (Essen Instruments, Ann Arbor, MI, USA) that has been previously described [35,57-60]. Briefly, GMCs were seeded in flat-bottom tissue culture plates and starved overnight by culturing in FBS/DMEM. The cells were treated with respective reagents, and the IncuCyte interface and software monitored their growth and kinetic activation of caspase-3/7.

\subsection{Western Immunoblotting}

Cultured GMCs were scrapped from flasks and homogenized in ice-cold RIPA buffer supplemented with a protease inhibitor cocktail (Thermo Scientific, Rockford, IL, USA). The proteins were then isolated and separated by 4-20\% ExpressPlus PAGE Gels (GenScript, Piscataway, NJ, USA) and transferred onto PVDF membranes using a Semi-Dry Blotter (Thermo Scientific). The membranes were blocked with a 5\% BSA blocking buffer for $\sim 1 \mathrm{~h}$ at room temperature. The membranes were then probed overnight at $4{ }^{\circ} \mathrm{C}$ with respective primary antibodies. After a wash in Tris-buffered saline supplemented with $0.05 \%$ Tween 20 (TBST), the membranes were probed with horseradish peroxidase-conjugated secondary antibodies for $45 \mathrm{~min}$ at room temperature and washed in TBST. The membranes were then incubated with a chemiluminescence reagent (Thermo Scientific), and the immunoreactive protein bands were visualized and documented using the ChemiDoc imaging system (Bio-Rad Laboratories, Inc., Hercules, CA, USA).

\subsection{Intracellular $\mathrm{Ca}^{2+}\left[\mathrm{Ca}^{2+}\right]_{i}$ Imaging}

GMCs cultured in glass-bottom dishes were washed with PBS and incubated with Fura-2-acetoxymethyl ester (Fura-2 AM; $10 \mu \mathrm{M}$ ), and 0.5\% pluronic F-127 for $\sim 1 \mathrm{~h}$ at room temperature in modified Krebs' solution $(134 \mathrm{mM} \mathrm{NaCl}, 6 \mathrm{mM} \mathrm{KCl}, 1.2 \mathrm{mM} \mathrm{CaCl}$, $1 \mathrm{mM} \mathrm{MgCl}_{2}, 10 \mathrm{mM}$ HEPES, and $5.5 \mathrm{mM}$ glucose, $\left.\mathrm{pH} 7.4\right)$. $\mathrm{Ca}^{2+}$ imaging was performed using a ratiometric fluorescence system (Ionoptix Corp., Milton, MA, USA) that has been previously described $[35,57,61]$.

\subsection{Determination of Mitochondria ROS and Mitophagy Assay}

The production of superoxides by the mitochondria was determined in live GMCs using the MitoSOX Red mitochondrial superoxide indicator Kit (Thermo Scientific). Live GMCs were loaded with $5 \mu \mathrm{M}$ of the MitoSOX reagent and Hoechst 33342 nuclear stain for $10 \mathrm{~min}$ at $37^{\circ} \mathrm{C}$. Following 3 washes, the cells were immediately visualized, and random fluorescence images were documented using a Zeiss LSM 710 laser-scanning confocal microscope.

Mitophagy was documented in sparsely seeded GMCs using a mitophagy detection kit (Dojindo Molecular Technologies Inc., Rockville, MD, USA) following the manufacturer's instructions. Briefly, the cells were washed with PBS and loaded with $100 \mathrm{nM}$ of Mtphagy dye (mitophagy staining) for $30 \mathrm{~min}$ at $37^{\circ} \mathrm{C}$. The cells were then washed and treated with DMSO (control) or DOX for $18 \mathrm{~h}$. The culture medium was removed, and cells were incubated in the dark with $1 \mu \mathrm{M}$ Lyso dye (lysosome staining) at $37^{\circ} \mathrm{C}$ for $30 \mathrm{~min}$. The cells were washed with PBS, after which the co-localization between Mtphagy (Ex. $561 \mathrm{nM} / \mathrm{Em}$. $650 \mathrm{nM}$ ) and Lyso (Ex. $488 \mathrm{nM} / \mathrm{Em} .502-554 \mathrm{nM}$ ) dyes were documented with a Zeiss LSM 710 laser-scanning confocal microscope.

\subsection{Antibodies (Catalog Numbers Are in Parentheses) and Chemicals}

Rabbit polyclonal anti-TRPC3 (AG1456), and anti-TRPC6 (ACC-120) antibodies were purchased from Abgent Inc. (San Diego, CA, USA) and Alomone Labs (Jerusalem, Israel), respectively. Mouse monoclonal anti-actin (ab3280) was purchased from Abcam (Cam- 
bridge, MA, USA). HRP-conjugated anti-rabbit (ab96919) and anti-mouse (ab98795) secondary antibodies were purchased from Abcam. All chemicals, unless otherwise stated, were purchased from Sigma-Aldrich (St. Louis, MO, USA). DOX and mitoquinone were purchased from LC Laboratories (Woburn, MA, USA) and MedKoo Biosciences (Morrisville, NC, USA), respectively.

\subsection{Data Analysis}

The Prism software (Graph Pad, Sacramento, CA, USA) was used for data analysis. Statistical significance was determined using the Student's $t$-tests for unpaired data and the Tukey's test for the analysis of variance for multiple comparisons. All data were expressed as the mean \pm standard error of the mean (SEM). A $p$-value of $<0.05$ was considered significant.

Author Contributions: Conceptualization, A.A.; experimentation, A.T.M., H.S., K.E.R.-F., T.A.J., R.K.B. and A.A.; writing - review and editing, A.A., A.T.M., K.E.R.-F. and R.K.B. All authors have read and agreed to the published version of the manuscript.

Funding: Adebiyi was supported by the National Institute of Health grants R01DK101668, R56DK120595, R01DK120595, and R01DK127625.

Institutional Review Board Statement: Animal use and welfare adhered to the National Institute of Health's (NIH) Guide for the Care and Use of Laboratory Animals. All experimental animal procedures were approved and performed following the Institutional Animal Care and Use Committee of the University of Memphis and the University of Tennessee Health Science Center guidelines.

Data Availability Statement: The data presented in this study are available upon reasonable request from the corresponding author.

Conflicts of Interest: The authors declare no conflict of interest.

\section{References}

1. Kitching, A.R.; Hutton, H.L. The Players: Cells Involved in Glomerular Disease. Clin. J. Am. Soc. Nephrol. 2016, 11, 1664-1674. [CrossRef]

2. Schlondorff, D.; Banas, B. The mesangial cell revisited: No cell is an island. J. Am. Soc. Nephrol. 2009, 20, 1179-1187. [CrossRef] [PubMed]

3. Schlondorff, D. The glomerular mesangial cell: An expanding role for a specialized pericyte. FASEB J. 1987, 1, 272-281. [CrossRef]

4. Ma, R.; Pluznick, J.L.; Sansom, S.C. Ion channels in mesangial cells: Function, malfunction, or fiction. Physiology 2005, 20, 102-111. [CrossRef]

5. Sours, S.; Du, J.; Chu, S.; Ding, M.; Zhou, X.J.; Ma, R. Expression of canonical transient receptor potential (TRPC) proteins in human glomerular mesangial cells. Am. J. Physiol. Ren. Physiol. 2006, 290, F1507-F1515. [CrossRef]

6. Vaughan, M.R.; Quaggin, S.E. How do mesangial and endothelial cells form the glomerular tuft? J. Am. Soc. Nephrol. 2008, 19, 24-33. [CrossRef]

7. Marciano, D.K. Mesangial Cells: The Tuft Guys of Glomerular Development. J. Am. Soc. Nephrol. 2019, 30, 1551-1553. [CrossRef] [PubMed]

8. Boyle, S.C.; Liu, Z.; Kopan, R. Notch signaling is required for the formation of mesangial cells from a stromal mesenchyme precursor during kidney development. Development 2014, 141, 346-354. [CrossRef] [PubMed]

9. Foo, S.S.; Turner, C.J.; Adams, S.; Compagni, A.; Aubyn, D.; Kogata, N.; Lindblom, P.; Shani, M.; Zicha, D.; Adams, R.H. Ephrin-B2 controls cell motility and adhesion during blood-vessel-wall assembly. Cell 2006, 124, 161-173. [CrossRef]

10. Grigorieva, I.V.; Oszwald, A.; Grigorieva, E.F.; Schachner, H.; Neudert, B.; Ostendorf, T.; Floege, J.; Lindenmeyer, M.T.; Cohen, C.D.; Panzer, U.; et al. A Novel Role for GATA3 in Mesangial Cells in Glomerular Development and Injury. J. Am. Soc. Nephrol. 2019, 30, 1641-1658. [CrossRef]

11. Nelson, T.; Velazquez, H.; Troiano, N.; Fretz, J.A. Early B Cell Factor 1 (EBF1) Regulates Glomerular Development by Controlling Mesangial Maturation and Consequently COX-2 Expression. J. Am. Soc. Nephrol. 2019, 30, 1559-1572. [CrossRef]

12. Boubred, F.; Vendemmia, M.; Garcia-Meric, P.; Buffat, C.; Millet, V.; Simeoni, U. Effects of maternally administered drugs on the fetal and neonatal kidney. Drug Saf. 2006, 29, 397-419. [CrossRef] [PubMed]

13. Hanna, M.H.; Askenazi, D.J.; Selewski, D.T. Drug-induced acute kidney injury in neonates. Curr. Opin. Pediatr. 2016, 28, 180-187. [CrossRef] [PubMed]

14. Schreuder, M.F.; Bueters, R.R.; Huigen, M.C.; Russel, F.G.; Masereeuw, R.; van den Heuvel, L.P. Effect of drugs on renal development. Clin. J. Am. Soc. Nephrol. 2011, 6, 212-217. [CrossRef] [PubMed]

15. Forfar, J.O.; Nelson, M.M. Epidemiology of drugs taken by pregnant women: Drugs that may affect the fetus adversely. Clin. Pharmacol. Ther. 1973, 14, 632-642. [CrossRef] [PubMed] 
16. Thorn, C.F.; Oshiro, C.; Marsh, S.; Hernandez-Boussard, T.; McLeod, H.; Klein, T.E.; Altman, R.B. Doxorubicin pathways: Pharmacodynamics and adverse effects. Pharm. Genom. 2011, 21, 440-446. [CrossRef] [PubMed]

17. Carvalho, C.; Santos, R.X.; Cardoso, S.; Correia, S.; Oliveira, P.J.; Santos, M.S.; Moreira, P.I. Doxorubicin: The good, the bad and the ugly effect. Curr. Med. Chem. 2009, 16, 3267-3285. [CrossRef] [PubMed]

18. Chatterjee, K.; Zhang, J.; Honbo, N.; Karliner, J.S. Doxorubicin cardiomyopathy. Cardiology 2010, 115, 155-162. [CrossRef] [PubMed]

19. Mitry, M.A.; Edwards, J.G. Doxorubicin induced heart failure: Phenotype and molecular mechanisms. Int. J. Cardiol. Heart Vasc. 2016, 10, 17-24. [CrossRef]

20. Lee, V.W.; Harris, D.C. Adriamycin nephropathy: A model of focal segmental glomerulosclerosis. Nephrology 2011, 16, 30-38. [CrossRef]

21. Dawrant, M.J.; Giles, S.; Bannigan, J.; Puri, P. Adriamycin produces a reproducible teratogenic model of vertebral, anal, cardiovascular, tracheal, esophageal, renal, and limb anomalies in the mouse. J. Pediatr. Surg. 2007, 42, 1652-1658. [CrossRef] [PubMed]

22. Kerr, J.R. Neonatal effects of breast cancer chemotherapy administered during pregnancy. Pharmacotherapy 2005, $25,438-441$. [CrossRef]

23. Pedrycz, A.; Wieczorski, M.; Czerny, K. Histological and histochemical assessment of the effects of a single dose adriamycin on fetal rat kidney. Acta Histochem. 2005, 107, 215-220. [CrossRef]

24. Pedrycz, A.; Wieczorski, M.; Czerny, K. Late effects of adriamycin single dose on fetal rat kidney-ultrastructural assessment. Environ. Toxicol. Pharmacol. 2005, 20, 157-160. [CrossRef] [PubMed]

25. Gonçalves, A.; França, W.G.; Moraes, S.G.; Pereira, L.A.; Sbragia, L. Adriamycin-induced fetal hydronephrosis. Int. Braz. J. Urol. 2004, 30, 508-513. [CrossRef]

26. Kajbafzadeh, A.M.; Sabetkish, N.; Sabetkish, S.; Javan-Farazmand, N.; Harsini, S.; Tavangar, S.M. The ameliorative effect of various antioxidants on Adriamycin-induced fetal renal abnormalities. J. Pediatr. Urol. 2013, 9, 1084-1092. [CrossRef]

27. Andrianova, N.V.; Buyan, M.I.; Zorova, L.D.; Pevzner, I.B.; Popkov, V.A.; Babenko, V.A.; Silachev, D.N.; Plotnikov, E.Y.; Zorov, D.B. Kidney Cells Regeneration: Dedifferentiation of Tubular Epithelium, Resident Stem Cells and Possible Niches for Renal Progenitors. Int. J. Mol. Sci. 2019, 20, 6326. [CrossRef] [PubMed]

28. Khoshdel Rad, N.; Aghdami, N.; Moghadasali, R. Cellular and Molecular Mechanisms of Kidney Development: From the Embryo to the Kidney Organoid. Front. Cell Dev. Biol. 2020, 8, 183. [CrossRef] [PubMed]

29. Steffes, M.W.; Osterby, R.; Chavers, B.; Mauer, S.M. Mesangial expansion as a central mechanism for loss of kidney function in diabetic patients. Diabetes 1989, 38, 1077-1081. [CrossRef]

30. Baker, A.J.; Mooney, A.; Hughes, J.; Lombardi, D.; Johnson, R.J.; Savill, J. Mesangial cell apoptosis: The major mechanism for resolution of glomerular hypercellularity in experimental mesangial proliferative nephritis. J. Clin. Investig. 1994, 94, $2105-2116$. [CrossRef]

31. Kahl, C.R.; Means, A.R. Regulation of cell cycle progression by calcium/calmodulin-dependent pathways. Endocr. Rev. 2003, 24, 719-736. [CrossRef] [PubMed]

32. Andrisani, O.M. CREB-mediated transcriptional control. Crit. Rev. Eukaryot. Gene Expr. 1999, 9, 19-32. [CrossRef]

33. Nijenhuis, T.; Sloan, A.J.; Hoenderop, J.G.; Flesche, J.; van Goor, H.; Kistler, A.D.; Bakker, M.; Bindels, R.J.; de Boer, R.A.; Moller, C.C.; et al. Angiotensin II contributes to podocyte injury by increasing TRPC6 expression via an NFAT-mediated positive feedback signaling pathway. Am. J. Pathol. 2011, 179, 1719-1732. [CrossRef]

34. Zhang, H.T.; Wang, W.W.; Ren, L.H.; Zhao, X.X.; Wang, Z.H.; Zhuang, D.L.; Bai, Y.N. The mTORC2/Akt/NFkB PathwayMediated Activation of TRPC6 Participates in Adriamycin-Induced Podocyte Apoptosis. Cell. Physiol. Biochem. 2016, 40, 1079-1093. [CrossRef] [PubMed]

35. Soni, H.; Adebiyi, A. TRPC6 channel activation promotes neonatal glomerular mesangial cell apoptosis via calcineurin/NFAT and FasL/Fas signaling pathways. Sci. Rep. 2016, 6, 29041. [CrossRef] [PubMed]

36. Frank, M.; Duvezin-Caubet, S.; Koob, S.; Occhipinti, A.; Jagasia, R.; Petcherski, A.; Ruonala, M.O.; Priault, M.; Salin, B.; Reichert, A.S. Mitophagy is triggered by mild oxidative stress in a mitochondrial fission dependent manner. Biochim. Biophys. Acta 2012, 1823, 2297-2310. [CrossRef]

37. Venditti, P.; Di Meo, S. The Role of Reactive Oxygen Species in the Life Cycle of the Mitochondrion. Int. J. Mol. Sci. 2020, 21, 2173. [CrossRef] [PubMed]

38. Schofield, J.H.; Schafer, Z.T. Mitochondrial Reactive Oxygen Species and Mitophagy: A Complex and Nuanced Relationship. Antioxid. Redox Signal. 2020. [CrossRef] [PubMed]

39. Sun, Y.B.; Qu, X.; Zhang, X.; Caruana, G.; Bertram, J.F.; Li, J. Glomerular endothelial cell injury and damage precedes that of podocytes in adriamycin-induced nephropathy. PLOS ONE 2013, 8, e55027. [CrossRef]

40. Miller, B.; Patel, V.A.; Sorokin, A. Cyclooxygenase-2 rescues rat mesangial cells from apoptosis induced by adriamycin via upregulation of multidrug resistance protein 1 (P-glycoprotein). J. Am. Soc. Nephrol. 2006, 17, 977-985. [CrossRef]

41. Sang, Y.; Tsuji, K.; Inoue-Torii, A.; Fukushima, K.; Kitamura, S.; Wada, J. Semaphorin3A-Inhibitor Ameliorates DoxorubicinInduced Podocyte Injury. Int. J. Mol. Sci. 2020, 21, 4099. [CrossRef]

42. Li, F.; Mao, X.; Zhuang, Q.; Zhao, Z.; Zhang, Z.; Wu, H. Inhibiting 4E-BP1 re-activation represses podocyte cell cycle re-entry and apoptosis induced by adriamycin. Cell Death Dis. 2019, 10, 241. [CrossRef] 
43. Yang, F.; Teves, S.S.; Kemp, C.J.; Henikoff, S. Doxorubicin, DNA torsion, and chromatin dynamics. Biochim. Biophys. Acta 2014, 1845, 84-89. [CrossRef]

44. Zhang, J.; Bi, R.; Meng, Q.; Wang, C.; Huo, X.; Liu, Z.; Wang, C.; Sun, P.; Sun, H.; Ma, X.; et al. Catalpol alleviates adriamycininduced nephropathy by activating the SIRT1 signalling pathway in vivo and in vitro. Br. J. Pharmacol. 2019, 176, 4558-4573. [CrossRef] [PubMed]

45. Huang, H.; You, Y.; Lin, X.; Tang, C.; Gu, X.; Huang, M.; Qin, Y.; Tan, J.; Huang, F. Inhibition of TRPC6 Signal Pathway Alleviates Podocyte Injury Induced by TGF- $\beta 1$. Cell. Physiol. Biochem. 2017, 41, 163-172. [CrossRef] [PubMed]

46. Dietrich, A.; Kalwa, H.; Rost, B.R.; Gudermann, T. The diacylgylcerol-sensitive TRPC3/6/7 subfamily of cation channels: Functional characterization and physiological relevance. Pflug. Arch. 2005, 451, 72-80. [CrossRef] [PubMed]

47. Trebak, M.; Vazquez, G.; Bird, G.S.; Putney, J.W., Jr. The TRPC3/6/7 subfamily of cation channels. Cell Calcium 2003, 33, 451-461. [CrossRef]

48. Aggarwal, V.; Tuli, H.S.; Varol, A.; Thakral, F.; Yerer, M.B.; Sak, K.; Varol, M.; Jain, A.; Khan, M.A.; Sethi, G. Role of Reactive Oxygen Species in Cancer Progression: Molecular Mechanisms and Recent Advancements. Biomolecules 2019, 9, 735. [CrossRef] [PubMed]

49. Conklin, K.A. Chemotherapy-associated oxidative stress: Impact on chemotherapeutic effectiveness. Integr. Cancer 2004, 3, 294-300. [CrossRef]

50. Yokoyama, C.; Sueyoshi, Y.; Ema, M.; Mori, Y.; Takaishi, K.; Hisatomi, H. Induction of oxidative stress by anticancer drugs in the presence and absence of cells. Oncol. Lett. 2017, 14, 6066-6070. [CrossRef]

51. Cappetta, D.; De Angelis, A.; Sapio, L.; Prezioso, L.; Illiano, M.; Quaini, F.; Rossi, F.; Berrino, L.; Naviglio, S.; Urbanek, K. Oxidative Stress and Cellular Response to Doxorubicin: A Common Factor in the Complex Milieu of Anthracycline Cardiotoxicity. Oxidative Med. Cell. Longev. 2017, 2017, 1521020. [CrossRef] [PubMed]

52. Gorini, S.; De Angelis, A.; Berrino, L.; Malara, N.; Rosano, G.; Ferraro, E. Chemotherapeutic Drugs and Mitochondrial Dysfunction: Focus on Doxorubicin, Trastuzumab, and Sunitinib. Oxidative Med. Cell. Longev. 2018, 2018, 7582730. [CrossRef]

53. Yin, J.; Guo, J.; Zhang, Q.; Cui, L.; Zhang, L.; Zhang, T.; Zhao, J.; Li, J.; Middleton, A.; Carmichael, P.L.; et al. Doxorubicin-induced mitophagy and mitochondrial damage is associated with dysregulation of the PINK1/parkin pathway. Toxicol. Vitr. Int. J. Publ. Assoc. BIBRA 2018, 51, 1-10. [CrossRef] [PubMed]

54. Catanzaro, M.P.; Weiner, A.; Kaminaris, A.; Li, C.; Cai, F.; Zhao, F.; Kobayashi, S.; Kobayashi, T.; Huang, Y.; Sesaki, H.; et al. Doxorubicin-induced cardiomyocyte death is mediated by unchecked mitochondrial fission and mitophagy. FASEB J. 2019, 33, 11096-11108. [CrossRef] [PubMed]

55. Liang, X.; Wang, S.; Wang, L.; Ceylan, A.F.; Ren, J.; Zhang, Y. Mitophagy inhibitor liensinine suppresses doxorubicin-induced cardiotoxicity through inhibition of Drp1-mediated maladaptive mitochondrial fission. Pharm. Res. 2020, 157, 104846. [CrossRef]

56. Gharanei, M.; Hussain, A.; Janneh, O.; Maddock, H. Attenuation of doxorubicin-induced cardiotoxicity by mdivi-1: A mitochondrial division/mitophagy inhibitor. PLoS ONE 2013, 8, e77713. [CrossRef] [PubMed]

57. Adebiyi, A.; Soni, H.; John, T.A.; Yang, F. Lipid rafts are required for signal transduction by angiotensin II receptor type 1 in neonatal glomerular mesangial cells. Exp. Cell Res. 2014, 324, 92-104. [CrossRef]

58. Soni, H.; Matthews, A.T.; Pallikkuth, S.; Gangaraju, R.; Adebiyi, A. $\gamma$-secretase inhibitor DAPT mitigates cisplatin-induced acute kidney injury by suppressing Notch1 signaling. J. Cell. Mol. Med. 2019, 23, 260-270. [CrossRef]

59. Soni, H.; Kaminski, D.; Gangaraju, R.; Adebiyi, A. Cisplatin-induced oxidative stress stimulates renal Fas ligand shedding. Ren. Fail. 2018, 40, 314-322. [CrossRef] [PubMed]

60. Soni, H.; Adebiyi, A. Urotensin II-induced store-operated $\mathrm{Ca}(2+)$ entry contributes to glomerular mesangial cell proliferation and extracellular matrix protein production under high glucose conditions. Sci. Rep. 2017, 7, 18049. [CrossRef]

61. Adebiyi, A. RGS2 regulates urotensin II-induced intracellular $\mathrm{Ca}^{2+}$ elevation and contraction in glomerular mesangial cells. J. Cell. Physiol. 2014, 229, 502-511. [CrossRef] [PubMed] 